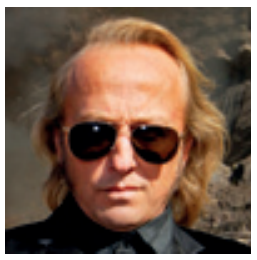

\title{
Alle forfattere bør ha sin egen lege
}

\section{Utveksling mellom lege og forfatter.}

Jeg tror aldri jeg er blitt så skuffet som da jeg møtte legen Christer Mjåset. Første gang vi hadde kontakt var da han sendte meg en e-post om hvorvidt det var fjerde juni eller fjerde juli 1973 Elvis Presley spilte i Saginaw, Michigan, eller kanskje spurte han om det var i Madison Square Garden trommeslageren til kongen, Don Tutt, for første gang brukte doble basstrommer.

Uansett var det et spørsmål av den typen. En type spørsmål jeg ikke klarte å svare på. Jeg hadde nettopp gitt ut min andre skjønnlitterære bok NedNedNed, og Mjåset skulle debutere samme år med En dans der veien slutter. Tilfeldighetene hadde tildelt oss samme redaktør på Gyldendal, og det var denne redaktøren som fikk forventningsfulle roser i kinnene da han fortalte at Christer Mjåset var lege. Og jeg må innrømme at jeg ble forventningsfull selv, en lege som også er forfatter! Jeg så for meg en fyr som bokstavelig talt gravde i den mørkere delen av mennesket.

I min verden finnes det ikke leger under 50 år. Det vil si det gjorde ikke det i 2003. Jeg ble derfor desillusjonert da vi endelig møttes og mannen jeg mistok for å være en basketballspiller faktisk var den sagnomsuste doktor Mjåset. Skuffelsen over at han var så ung var imidlertid ikke det verste, nei, alderen kunne jeg alltids leve med, men den Cary Grant-aktige framtoningen? Når du først er lege og samtidig forfatter bør du ha noe suspekt over deg. Jeg hadde sett for meg en Louis-Ferdinand Céline-type. Smått forsoffen med en luguber fortid, dunkle politiske tilbøyeligheter og en hang til å ta for seg av ting han i utgangspunktet skulle skrive ut til pasientene.

Det var ikke fritt for at jeg også tenkte på dr. Wilbur Larch, abortlegen i John Irvings Siderhusreglene, som hadde en hang til å ta fram eterflaska til privat bruk. Ja, for ikke å glemme sir Arthur Conan Doyle. Jeg visste riktignok ikke om den britiske legen og forfatteren delte forkjærligheten for opium og morfin med sin store detektivhelt Sherlock Holmes, men Conan Doyle gjorde seg i hvert fall interessant med blant annet å lefle med spiritismen. Doktor Christer Mjåset derimot kom meg i møte som om han nettopp skulle ha steget ned fra bildet på en mjølkekartong.

Jeg ga imidlertid ikke opp håpet om at han ville leve opp til mitt fordomsfulle bilde av en lege slash forfatter. Han kunne jo bedrive en eller annen form for forfinet, samtidig litt halvsuspekt sport. Fekting eller hestepolo. Eller muligens kunne de lange, delikate fingrene bli til små drapsmaskiner som han brukte i en gammel asiatisk kampsport. Det nestførste jeg spurte Christer Mjåset om var derfor om han drev noen sport. «Ja,» sa han, «jeg har drevet mye med svømming.»

Etter hvert som jeg har lært Christer Mjåset å kjenne må jeg si at jeg er glad at det er lite Louis-Ferdinand Céline over ham. For han har etter hvert utviklet seg til å bli en av de aller viktigste menneskene i livet mitt når det gjelder å snakke om å skrive. Og jeg må komme med en liten innrømmelse. Det er helt uvurderlig å ha en skrivende lege i omgangskretsen. Fordelene er åpenbare. Jeg slipper å bruke timevis på research, og kan bare sende Mjåset en e-post. «Når man blir skutt i hodet, kan man si at blodet som renner kan se ut som vin som strømmer ut over en duk?» kan jeg spørre. «Ja,» sier han. «Kan man bli steril av å falle ned av stiger når man overrasker kona i seng med faren sin på sin femte bryllupsdag?» spør jeg videre. «Ja,» sier han. «Men kan man si at blodet klukker ut av brystet?» kan jeg fortsette. «Ja,» sier han. «Hvis du vil skrive dårlig krim, kan du det.»

Jeg har også lært meg nok legesjargong til at jeg kan posere som fødselslege i selskapslivet, vel å merke ganske sent på kvelden. «Fontanell» og «mormunn» vet jeg nå hva er.

En annen fordel er alle pengene jeg sparer. Det ligger i kortene at jeg er litt hypokonder, og da er det fort gjort å sende noen symptomer til Mjåset og late som dette er noe jeg skal bruke i en historie. Men jeg tror han er i ferd med å bli litt mistenksom. Sist jeg følte meg litt uvel og kamuflerte det som et fiktivt problem, svarte han skeptisk: «Det er mye sjukdom blant de folka du skriver om.»

Dessverre er det også noen ulemper. Han kommer veldig mye bedre ut av denne utvekslingen av e-poster enn meg. Hvis det noen gang skal skrives en biografi om oss, vil jeg fortone meg som en brystsvak svekling, mens Mjåset vil framstå som klar, analytisk og alltid med gode, velfungerende løsninger. Men slik er vel både en pasients og en leges lodd her i livet.

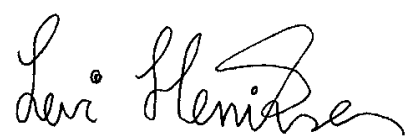

Troponinmåling

Nyfødtscreening

Svangerskapkomplikasjoner og schizofreni
Malaria

Inflammatorisk tarmsykdom

Pasientskademeldinger 